\title{
Joint projects see ocean science aiming high
}

Mark Schrope

When former US President John F. Kennedy helped to launch the age of space exploration, he predicted that space would be the new ocean. But 40 years on, it is ocean scientists who are looking to space for the technologies and methodologies to fuel their own new age.

Despite some obvious crossovers between space and ocean sciences, the collaborations have never really met their full potential, says Craig McLean, director of the National Oceanic and Atmospheric Administration's Office of Ocean Exploration. But that is now starting to change.

Space scientists, for example, are aching to search for life in aquatic environments beyond Earth, such as Jupiter's moon Europa. Oceanographers can offer some of the tools for this research, and would in return benefit from space funding both to improve these instruments and to develop new equipment. And space scientists know that the oceans are an ideal testbed for tools, such as sensors, needed for their projects.

Last month at the Kennedy Space Center in Florida, Mclean's office and NASA's oceanography programme co-sponsored a meeting called the Link Symposium, to foster such collaborations.

Many of the discussions at the meeting addressed shared needs for new technologies, such as better and smaller mass spectrometers that could serve a variety of purposes on both underwater vehicles and space probes.

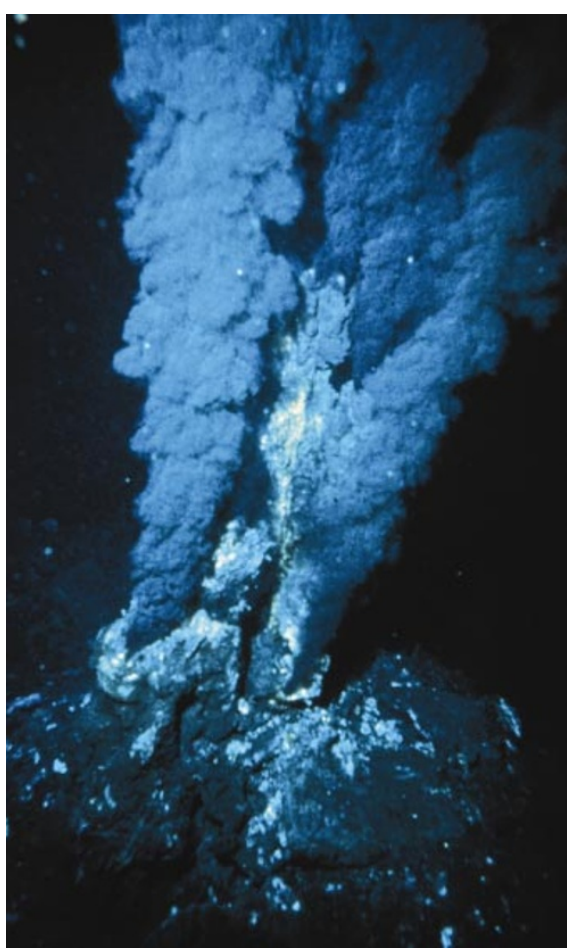

Think big: those studying seafloor features are hoping to emulate the scope of NASA's projects.

Some such partnerships already exist. Ocean engineers, for example, have worked with their space counterparts to design vehicles to explore Europa's ocean. The two fields have also cooperated on the development and testing of sensor webs, networks of electronics pods that can be fitted with a variety of sensors. "I think right now we are on the front end of this collaboration, which I am very confident will bear fruit," says McLean.

But the tendency of the two fields to think and operate on different scales presents a barrier to collaboration, says Eric Lindstrom, head of NASA's oceanography programme. "They don't speak the same language," he says. Space scientists tend to start with a long-term goal and then build what is needed, from scratch if necessary. Far smaller budgets have obliged oceanographers to strive for more incremental advances.

Some oceanographers hope to break this mould. For instance, Project Neptune is an ambitious plan led by researchers at the University of Washington in Seattle to wire an entire seafloor tectonic plate with sensors and equipment to monitor its geology, biology and chemistry.

At a cost of around $\$ 250$ million, the project, if it gets funded, would be comparable in scale to a typical NASA mission - making it the largest ocean-science project ever. Partly because of Neptune's similarities to space projects, NASA's Jet Propulsion Laboratory in Pasadena, California, is a partner in the project.

"Enormous changes have to go on in evolving from individual principal-investigator science to big science," says James Bellingham, director of engineering at the Monterey Bay Aquarium Research Institute in Moss Landing, California, and a coordinator of the Florida meeting.

www.thelinkproject.org

\section{US postal service puts anthrax detectors to the test}

\section{Jonathan Knight, San Francisco}

Automated anthrax-sniffers will be making their debut in selected US post offices this summer. The US Postal Service (USPS) is already testing the equipment with an eye to installing it nationwide in all of its 400 or so mail-sorting facilities by next year.

The USPS hopes that the equipment, which detects the DNA of the anthrax bacterium, Bacillus anthracis, will prevent, or at least mitigate, the effects of any future bioterrorist attacks through the mail. In last October's attacks, anthrax spores contaminated several post offices after being dispersed into the air by mail-sorting machines, killing two postal workers.

A \$3.7-million trial to be carried out at several sorting offices on the east coast will test a detector produced by Northrop Grumman, an aerospace contractor based in Baltimore, Maryland. The device continuously channels samples into a detection unit that screens for DNA from the anthrax bacterium.

A similar device designed by Lockheed Martin has not yet entered field tests.

Whichever system is chosen will be installed nationwide and paid for, in part, by $\$ 200$ million in emergency funding that Congress set aside last autumn for the project.

The detectors in Northrop Grumman's system are made by the biotechnology company Cepheid of Sunnyvale, California. They rely on the polymerase chain reaction (PCR) to single out and amplify regions of DNA found in the toxicity gene of anthrax. A molecular tag turns fluorescent if it finds amplified DNA fragments to bind to, activating the alarm within half an hour of sample collection. If the gene is not present, no DNA is produced. A worker would periodically replenish the disposable reaction chambers in the detector, but the system requires little other maintenance.
All detection systems carry a risk of crying wolf with 'false-positive' results. Cepheid operations chief Kurt Petersen says that controls built into the PCR system should minimize these, but they won't know for sure how well they work until the tests are complete. For example, the system could run a second test to confirm a positive result before a facility is evacuated. "We are entering a realm of DNA testing that has never been done before," he says.

The trade-off in eliminating false positives is missing some genuine positives, says Martin Blaser, a microbiologist at the New York University Medical School who has studied last October's anthrax attacks. But he says it is better to risk missing some traces of anthrax than to panic postal workers and erode their trust in the system by raising too many false alarms. "We won't be able to develop a system that will protect everybody," he warns. 